\title{
THE BARRIERS OF E-GOVERNMENT SUCCESS: AN EMPIRICAL STUDY FROM JORDAN
}

\author{
Ammar Salamh Mujali Al-rawahna ${ }^{1}$, Shih-Chih $\mathrm{Chen}^{2} *$ and Chung-Wen Hung ${ }^{3}$ \\ ${ }^{2}$ National Kaohsiung First University of Science and Technology, Kaohsiung, Taiwan \\ ${ }^{1,3}$ Southern Taiwan University of Science and Technology, Tainan, Taiwan
}

\begin{abstract}
This paper discussed the E-governmentsuccess barriers and how could these barriers affect in users' dissatisfaction as measure ofE-governmentsuccess. The model explained more embedded relations of Information System (IS) success model in a negative context. E-governmentquality model encompasses information quality, system quality, service quality and IT infrastructures readiness, which are the predecessors of user satisfaction as measure of E-government success. The research model has been empirically tested using 93 IT managers and IT specialists of Jordanian government agencies. PLSstructural equation modeling (SEM)has been used because his superior statistical power in dealing with complex causal model and small sample size. The results clearly articulated that provisionede-services are less than expectationsof stakeholders. We found that lack of IT infrastructures readiness is the strongest factor to affect in E-governmentperformance negatively and the most important factor to provoke users' dissatisfaction. Along with the other factors were found significantly correlated with users' dissatisfaction.The relation of system quality with services quality only the difference between female and male group, where male group found its insignificant while females found thatlow system quality led to low service quality directly.
\end{abstract}

\section{KEYWORDS}

E-governmentbarriers, Information System (IS) success model, Jordanian E-government

\section{INTRODUCTION}

E-government (E-Gov) provides significant opportunities to transform public administration into an instrument of sustainable development[1]. E-Govdescribed as an interaction of government with citizens, public and private sectors by means of communication technology to provide services effectively and efficiently and to communicate with all parties interactively[2]. The EGov should provide high-quality services that are clearly geared to produce meaningful and needed public values through suitable IT means. Basically, the E-Gov evolution stagesare presenting, assimilating, reforming, morphing and e-governance with two underlying themes surface: citizen/service and operation/technology[3].Each E-Gov stage has its special challenges and more barriers will appear with advancing in E-Gov sophisticated stages.However, while the developed countries compete to provide more advanced services, developing countries still unable to reap the basic benefits of E-Gov[1], [2], [4]. There are some barriers in public sector preventing the realization of anticipated benefits and hinder successful adoption of E-Gov. The efforts of developing countries toward electronic transformation seem to be somewhat fruitless. The usage average of E-Gov less than 50 percent among developing countries, and great variation compared with developed countries in use of more advanced services such as services require robust security and online payment(see [1]\&[5]). For instance, Jordanian government adopted EGov since 1999 to improve its services and decrease the operational costs [6].The Jordanian EGovis unsuccessful yetin achieving its goals completely. UNs' surveys have shown that Jordanian E-Gov rank declined (see Table 1). Generally, the main barriers of E-Govsuccess are lack of DOI: 10.5121/ijmpict.2018.9201 
International Journal of Managing Public Sector Information and Communication Technologies (IJMPICT)

Vol. 9, No. 2, June 2018

security and privacy, mistrust, lack of resources, digital divide, poor management, lack of awareness, legal barriers, lack of infrastructure, and resilience[7].More specifically, Jordan still lagging behind in utilizing information and communication technologies for delivering government services online[6]. However, the systematic review for studies between (1992-2007) that adopted Information System success model found that IT infrastructure the second strongest predictor of IS success[8]. These studies have consistently found positive relationships between IT infrastructure with information quality, use, and organizational impact. Therefore, without a robust infrastructure organization could not build trust relation between all the stakeholders of EGov and encourage them to adopt it. Rana et al[7],called for in-depth research to undertake the EGov supply-side challenges in developing and under-developed countries, ahead of analyzing the issues related to E-Gov adoption becauseE-Gov research in those countries insufficient. Therefore, this study purpose is to highlight the most important technological-related barriers of E-Gov from perspectives of services provider of government agencies in order to help decision makers take the informed decision to direct e- government program into success path.

\subsection{E-Government Rank and Problem Statement}

The United Nation since 2005 have established assessment to rank countries based on the degree of E-Gov development. The UN survey ranks countries based on e-participation index and E-Gov development index. The participation indexes are ("e-information sharing"); interaction with stakeholders ("e-consultation"); and engagement in decisionmaking processes ("e-decision making")[1]. These indexes focus on use online services to facilitate provisions of information by governments to citizens. However, Table 1 shows the Jordan rank among 193 of UNs members for years between 2005 and 2016; the survey conducted every two years. The $2012 \mathrm{UN}$ report indicated that Jordan retreated (47) degrees comparing with 2010 assessment where has been ranked (51) (see [5]).Notably, Jordan rank declined in the last assessment in 2016 after slightly improved in 2014.

Table 1 Jordanian E-Gov Rank by UN

\begin{tabular}{|l|c|c|c|c|c|c|}
\hline Year & $\mathbf{2 0 1 6}$ & $\mathbf{2 0 1 4}$ & $\mathbf{2 0 1 2}$ & $\mathbf{2 0 1 0}$ & $\mathbf{2 0 0 8}$ & $\mathbf{2 0 0 5}$ \\
\hline E-Gov development index & 91 & 79 & 98 & 51 & 50 & 68 \\
\hline E-participant index & 98 & 71 & 101 & 42 & 17 & 90 \\
\hline
\end{tabular}

Table 2 presenting further details of assessment criteria. The E-Gov Development Index (EGDI) represents the degree of E-Gov development for countries of United Nations. Along with an assessment of the website development patterns in a country, the EGDI incorporates the access characteristics, such as the infrastructure and educational levels, to reflect how a country is using information technologies to promote access and inclusion of its people. The EGDI is a composite measure of three important dimensions of E-Gov, namely: provision of online services, telecommunication connectivity and human capacity (explained in [5]).

Table 2 Jordanian E-Gov rank based on EGDI

\begin{tabular}{|l|c|c|c|c|c|}
\hline Year & $\mathbf{2 0 1 6}$ & $\mathbf{2 0 1 4}$ & $\mathbf{2 0 1 2}$ & $\mathbf{2 0 1 0}$ & $\mathbf{2 0 0 8}$ \\
\hline Online Service Index & 0.456 & 0.519 & 0.392 & 0.533 & 0.605 \\
\hline Telecommunication Infrastructure Index & 0.345 & 0.31 & 0.271 & 0.18 & 0.169 \\
\hline Human Capital Index & 0.734 & 0.72 & 0.8 & 869 & 0.867 \\
\hline
\end{tabular}

Notably, Jordanians do not lack the technical competencies to use the internet and information technology applications whereAl-Soud et al.[9], indicated that 75.7 percent are able to use 
International Journal of Managing Public Sector Information and Communication Technologies (IJMPICT)

Vol. 9, No. 2, June 2018

internet services andAbu-Shanab et al.[10], reported that spread of internet 85 percent in north of Jordan. The results of UN surveys in Table 2 affirmed that, the average of human capital index always good where (0.72) was the lowest average in 2014 and this above the world and region averages. The shortage of required resources one of barriers to successof E-Govs where the averages of telecommunication infrastructure index always lower than the world and regional average. The online service index shows that Jordan average above the world average but still lower than regional average (see [1]).The E-Gov program in Jordan still lagging behind in utilizing information and communication technologies for delivering government e-services [11].The comprehensive study that cover whole Jordan byAl-Soud et al.[9], revealed that more than 60 per cent out of (4294) respondents (citizens) do not actually know about E-Gov services and the worst result 70 percent of who used the E-Gov services found it not useful. Another study in northern Jordan found that usage of E-Gov 36 percent of the sample.Therefore, this study aims to quest the reasons led participants to gauge E-Gov in Jordan as such.

\section{LITERATURES REVIEW}

This section presents an overview for barriers of E-Gov. At beginning, exhibiting the main barriers of E-Govsuccess in order to define the technological-related barriers. This step paved the way to construct the research model based on IS success model. The study tried to bridge the gap of previous studies by determining the barriers of E-Gov success form perspectives of IT managers and IT specialists empirically. The respondents themselves will evaluate their E-Gov program andprovisioned services through quality criteria (system quality, information quality, service quality and user satisfaction).It's important for governments after two decades of releasing the E-Govs' initiatives to revise their E-Gov strategies and to see if the promised advantages actually harvested or it will remain elusive for developing countries.

\subsection{E-Government Barriers}

The main focus of this sectionpresentingthe E-Gov barriers in general. Eynon and Dutton [12] defined the E-Gov barriers as "Characteristics - either real or perceived - of legal, social,technological or institutional context which work against developing E-Gov, either: because they impede demand, by acting as a disincentive or obstacle for users to engage with EGov services; or because they impede supply, by acting as a disincentive or obstacle for public sector organizations to provide E-Gov service ".Nemours of study conducted a systematic review and some case studies to identify theE-Gov barriers (see [7], [12]-[14]). The systematic reviews gave a holistic view for these barriers that allowed us to build based on it then we don't need to reinvent the wheel again. It's covering across a span of time from early evolution stages E-Gov to the advance stages and from developing into developed countries. 
International Journal of Managing Public Sector Information and Communication Technologies (IJMPICT) Vol. 9, No. 2, June 2018

Table 3E-Gov barriers

\begin{tabular}{|c|c|c|}
\hline Categories & E-Gov Barriers & Reference \\
\hline \multirow{6}{*}{ Strategy } & Absence of implementation guidance & [15] \\
\hline & Unclear vision and management strategy & [13] \\
\hline & Over-ambitious E-Gov milestones & [15] \\
\hline & Lack of shared E-Gov goals and objectives & {$[15]$} \\
\hline & Lack of ownership and governance & [15] \\
\hline & $\begin{array}{l}\text { Funding issues and centralization of funding for government } \\
\text { agencies }\end{array}$ & {$[16]$} \\
\hline \multirow{9}{*}{$\begin{array}{c}\text { Technological } \\
\& \text { IT } \\
\text { infrastructure }\end{array}$} & Lack of architecture interoperability and systems integration & {$[12],[16]$} \\
\hline & Different security models & {$[15]$} \\
\hline & Inflexibility of legacy systems & [13], [15] \\
\hline & Incompatible of technical and data standards & {$[12],[15]$} \\
\hline & Privacy and security issues such as online theft and fraud & $\begin{array}{l}{[12],[14],[16]-} \\
{[18]}\end{array}$ \\
\hline & Shortage of reliable networks and low bandwidth & {$[12],[13],[16]$} \\
\hline & Inadequate security of government hardware and software & {$[13],[16]$} \\
\hline & Unauthorized external and internal access to information system & {$[6],[12]$} \\
\hline & Lack of open sources software and standards & {$[14]$} \\
\hline \multirow{5}{*}{$\begin{array}{l}\text { Policy } \\
\text { \& legal }\end{array}$} & Lack of legal bases and comprehensive policy & $\begin{array}{c}{[14],[17]} \\
{[19][13]-[15]} \\
\end{array}$ \\
\hline & Lack of security rules, policies and privacy law & {$[13]-[15]$} \\
\hline & Data ownership conflicts & {$[15]$} \\
\hline & Lack of political commitment and coordination & {$[12],[14],[20]$} \\
\hline & Digital divide & {$[9],[14],[20]$} \\
\hline \multirow{8}{*}{$\begin{array}{l}\text { Organizational } \\
\quad \& \text { cultural }\end{array}$} & Lack of relevant in-house management and IT skills & {$[7],[15],[17],[21]$} \\
\hline & $\begin{array}{l}\begin{array}{l}\text { Complexity of reengineering government processes and } \\
\text { procedures }\end{array} \\
\end{array}$ & {$[13]$} \\
\hline & Lack of knowledge for security risks & [13] \\
\hline & Slow pace of government reform & {$[15]$} \\
\hline & Lack of agency readiness & {$[15]$} \\
\hline & $\begin{array}{l}\text { Lack of cooperation and coordination between government } \\
\text { agencies }\end{array}$ & {$[10],[12]$} \\
\hline & Lack of effective leadership support & [12], [22] \\
\hline & Resistance to change & {$[14],[12]$} \\
\hline \multirow{3}{*}{$\begin{array}{l}\text { Operational } \\
\text { Cost }\end{array}$} & Cost of installation, operation and maintenance of E-Gov system & {$[12],[14]$} \\
\hline & Cost of training, IT professional and consultants & {$[22]$} \\
\hline & Shortage of financial resources in public sector & {$[10],[22]$} \\
\hline
\end{tabular}

Two studies conducted a comprehensive systematic review for understanding and analyzing challenges, barriers and critical success factors of E-Gov adoption(see [7], [14]).Nkohkwo \& Islam. [23], reviewed the challenges of successful implementation of E-Gov initiatives in African countries. Ashaye and Irani. [22], investigated benefits and barriers of E-Gov implementation in African countries with evidence from Nigari. Eynon and Dutton [12]identified barriers of E-Gov empirically across Europe countries such as poor coordination; workplace and organizational 
International Journal of Managing Public Sector Information and Communication Technologies (IJMPICT) Vol. 9, No. 2, June 2018

inflexibility. Lam [15] focused on the barriers that hinder E-Gov integration whileEbrahim, [13] surveyed the barriers of adoption E-Gov theoretically. Waller and Genius, [16] investigated the barriers to transforming E-Gov in Jamaica. Most of studies focused on exploring implementation challenges/barriers whereas fewer studies discussed the challenges/barriers associated with adoption[7].A group of studies indicated the barriers and challenges of E-Gov in Jordan specifically (see [6], [9], [10], [17], [24]). Theypresented the barriers from two different perceptions. The first, government agencies(services providers) have explored the following barriers: IT infrastructure; lack of awareness; lack of security and privacy; lack of trust; lack of a comprehensive policy; legal and regulatory framework; insufficient skilled human resources; lack of public-private collaboration/partnerships; lack of training and knowledge transfer; lack of EGov transformation and resistance to change; budgets and operating costs and lack of clear strategy[17].Elsheikh et al. [6], explored the technological challenges specially issuing and adopting standards for system interoperability and data exchange, setting up secured networks based on common standards, developing shared applications (e.g. e-procurement), introducing digital signatures, and authentication. On the other hand, the reasons of non-adoption E-Gov servicers from citizens' perspectives referred to prefer face-to-face services, mistrust in e-services, lack of financial ability to buy computer and subscribe to internet, useless and for reasons of privacy and security[9]. Also, inadequate the legislation and regulations governing electronic transactions[10]. Jordanians prefer face-to-face services;Alomari et al[24], referred that to cultural factor of favoritism, also known as "wasta". They add more cultural factors such resistance to change and digital divide which means IT infrastructure centric in main cities and neglect the small and rural areas, financial ability. Notably, the overlap between technological, cultural and organizational factors that affect E-Gov adoption and success. However, the studies placed in Jordan did not investigate the impact of E-Gov services quality on citizens' satisfaction and other stakeholders. Therefore, this study focuses ontechnological, IT infrastructures and information systems barriers.Without overlooking the importance of reform managerial, organizational, cultural and legal barriers to underpin the success ofE-Gov program. Otherwise, these barriers will hinder the success of E-Govprogram even thoughthe technical barriers reformed. Organizations will have more free time to focus on core business, increase the users' awareness and build trust relation with them. The cost saving as one of E-Gov advantages will available more resources to bridge the digital gap. Many studies indicate that bandwidth speed and internet accessibility are of major barriers therefore without improving the national network;E-Gov program will be unable to achieve all promised advantages.

\subsection{E-Government Quality Model}

The study targeted the technological-related barriers and other associated barriers with E-Gov interactions such as e-services quality. The barriers grouped in regarding to Information System (IS) success model. "IS success" model widely used to evaluate success of information systems and web-based systems for example e-commerce and E-Gov. The model developed by Delone and McLean in 1992 and updated in 2003 and 2013[8]. The IS success model encompasses six major constructs represented the main features of information system there are: information quality, system quality, services quality, intention to useluse, satisfaction, and net benefits. Wang and Liao,[25]concluded that IS success models can be extended to investigating E-Gov systems success. However, E-Gov has unique characteristics that represent the levels of functionality and technical aspects of E-Gov systems and applications. These characteristics provide a way of measuring the success ofE-Gov initiatives in terms of how they meet technical requirements such as usability, quality of information, privacy, or security[26]. In addition, they reflect the level of sophistication of these systems and readiness of technological infrastructures. Stefanovic et al. [27],Error! Reference source not found.found that updated IS success model can be adapted to 
measure E-Gov system success from the employees' perspective. The empirical research in EGov adoption and success area needed and would find more facts related to the factors and their performances on challenges, barriers, and critical success factors[7]. As the focus of this study is on the barriers of E-Govsuccess from perspective IT managers and IT specialists of government agencies. This study adapted IS success model to investigate the impact of E-Gov barriers on users' dissatisfaction as measure of E-Gov success. For purpose of this study, the E-Gov success barriers were categorized into system quality, information quality, services quality and IT infrastructure readiness. These factors gauge the impact of E-Gov barriers in dissatisfaction of EGov users. Each construct in

Figure 1 has been explained below with its related hypotheses.

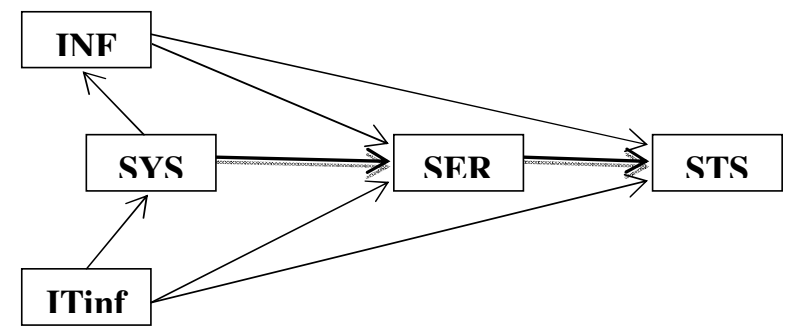

Figure 1 Research Model

\subsubsection{System quality(SYSQ)}

The parameters of system quality are usability, security, customizability, flexibility, reliability, functionality, and integration used to measure the system quality to process the information[28]. The IS success model distinguished the software barriers from IT infrastructure barriers unlike Waller \& Genius [16], where software barrierslisted under IT infrastructure barriers. The result of meta-analysis to IS success model revealed that system quality has significant impact on the intention to use system, actual use and user satisfaction[29]. Incompatibilities between E-Gov systems or difficulty to use E-Gov services exemplify a serious operational obstacle to E-Gov systems in Europe union[12].Stefanovic et al [24], and Wang \& Liao [27]found system quality important factor to achieve users satisfaction and encourage their intention toward the usage of E-Gov systems. As well as, the system quality is responsible about taxpayers' satisfaction[30]. In the negative side, the study ofAl-Soud et al.[9], revealed that system security one of the major barriers that prevented Jordanian citizens from adopting E-Gov services. In addition, the inflexibility of legacy systems, incompatible technical standards and lack integration of government different system and databases are the main drawbacks to E-Gov success[15], [31]\&[14]. Another related berries to system quality, cost of installation, operation and maintenance of E-Gov system; cost of training, IT professional and consultants and shortage of financial resources in public sector[6], [14] \& [16]. Eynon and Dutton.[12], reported barriers related to system design difficult of use E-Gov applications. The environment of E-Gov is importantto operate E-Govsystems that could reflex on system quality performance. This study presenting new assumption, that negative evaluation of system quality is related to negative quality of e-services. Therefore, the first posit "H1": There is statistically significant correlation between the negative evaluation of system quality and the lowquality of e-services based on perceptions of IT manager and IT specialists." The information is output of E-Gov system. Based on in this conclusion, the second posit "H2": There is statistically significant correlation between the negative evaluation of system quality and the negativity of information quality based on perceptions of IT managers and IT specialists." 


\subsubsection{Information quality (INFQ)}

The parameters of information quality described based on IS success model, as such understandability, usability accessibility, accuracy availability, integration and compatibility[28]. The data nonexistence, or its poor quality, is one of the main obstacles in the process of developing information systems[26]. Availability and quality of information determine the functionality of E-Gov applications. The "IS success" meta-analysis's asserted that information quality is the determinant of system use and user satisfaction that eventually leads to adopt eservices[29].Shareef et al. [32], reported a negative relation between perceived information quality and adoption of E-Gov. Important to note that most of Jordanians using E-Govservices for information inquiry[9].Luna-Reyes et al. [6] and Rana et al. [23]cited that web content and information quality are among challenges and determinants success of E-Gov. Result of Wang \& Liao [25]supported this perception;information quality had a significant influence on both usage of E-Gov services and user satisfaction.Gilbert et al. [33], reported a strong correlation between information quality and willingness to use E-Gov services. Therefore, this study posits that negative information quality as a determinant factore-services quality tousers' satisfaction. Regarding to E-Gov challenges, this factor addressed to identify drawbacks of information quality that provided by Jordanians' government agencies. Thus, the thirdposit"H3": There is statistically significant correlation between the negative evaluation of information quality and the users dissatisfaction -as a measure unsuccessful of E-Gov- based on perceptions of IT managers and IT specialists." The information is a result of interaction of E-Govusers withe-services.LunaReyes et al.[26],model suggested that information quality and technological infrastructure as a determinant and indicator on improvements of public services quality. Therefore, the study posits the fourth hypothesis "H4": There is statistically significant correlation between the negative evaluation of information quality and the negativity of e-services quality based on perceptions of IT managers and IT specialists."

\subsubsection{Service quality (SERVQ)}

IT departments or organizations measuring and comparing users' expectations against their perceptions of the service[8]. The responsiveness, reliability and technical competence, empathy are the main parameters to evaluate e-services quality[29]. Responsiveness and empathy are important to users when they need help with a specific system[8].Wang \& Liao [25]provided evidence that e-services quality responsible about users' satisfaction and induce them to use the E-Gov services. Similarly, Chen [30], found that e-services quality important factor to achieve users' satisfaction. In contrary,Stefanovic et al.[27], found insignificant relation between services quality and government employees' satisfaction.Al-Soud et al. [9], reported 60 percent of Jordanians lack the awareness of E-Gov services and 70 percent of who used them found it not useful. Lack of confidence and trust to use E-Gov services are critical barriers to E-Gov success in Jordan[10], [17]. Perceived trust of citizens is related to the credibility of E-Gov. The response to citizens needs could help to enhance the perception of trust and credibility, particularly in the virtual environment, among the users of E-Gov[32], [33]. Indeed, if citizens or any user feel EGov services poor quality or not matching their needs, website services unsecure they are less likely to adopt it. Trust in e-services was often associated with transactions security and trust in government in preserving personal data privacy[34]. Liang [35], confirmed this argument where found that trust in E-Gov positively affected users' intentions to use cloud based e-invoice services. Stefanovic et al.[27], reported significant relation between services quality and the usage of E-Gov services.Government has to think outside the box to improve its organizational and technical capability and be able to satisfy stakeholders' needs. The assumption in this argument, how the E-Gov agencies evaluate their e-services provided to the audiences? Does deficiency of e-services affect users dissatisfaction?Therefore, the fifthposit "H5: There is statistically significant correlation between the negative evaluation ofe-services and the users dissatisfaction as a measure unsuccessful of E-Gov- based on perceptions of IT managers and IT specialists." 


\subsubsection{IT infrastructure readiness (ITinfra)}

Three important dimensions that allow people to benefit from online services; these are: the adequacy of telecommunication infrastructure, the ability of human resources to promote and use ICT, and the availability of online services and content[5], [34]. In the new suggested model of IS success,Petter et al.[8], defined IT infrastructure as the degree of sophistication of the IT infrastructure within the organization. For purpose of this study, IT infrastructure more border to include the IT infrastructure inside and outside the organization border.Network and IT infrastructure preparedness are important indicators for ranking E-Gov development. Waseda University measuring this indicator by three sub-indicators internet users, broadband subscribers and Mobile Cellular subscribers[34].Governments face a shortage of technical infrastructure[31]. The main challenges plaguing success of E-Gov initiatives in African countries are ICT infrastructure[23]. The ICT infrastructure barriers to implementing E-Gov in Jamaica included, hardware telecommunication systems, the electricity/power grid, computers network[16]. Advances in E-Gov must go hand in hand with efforts to bridge the digital divide. Thus, requires improving access to high-speed broadband connection for all through reliable and high-quality infrastructure that influences digital inclusion.Otherwise Lack of bandwidth capacity will limit expanding E-Gov service and extend the digital divide[14].UnitedNation [11],survey affirmed that average of telecommunication infrastructure readiness in Jordan (0.345)). Jordan average is always less than the world average (0.37) and the sub-regional average (0.373). As well as, the systematic review (1992-2007) for the studies that adopted IS success model found that IT infrastructure the second strongest predictor of IS success[8]. These studies have consistently found positive relationships between IT infrastructure with information quality, use, and organizational impact. Therefore, without a robust infrastructure organization could not build trust relation between all the stakeholders of E-Gov and encourage them to adopt it.Therefore, the sixthposit"H6": There is statistically significant correlation between the negative evaluation of IT infrastructure and the users dissatisfaction -as a measure unsuccessful of E-Gov- based on perceptions of IT managers and IT specialists." The information is a result of interaction of EGov users with e-services. Based on in this conclusion the study posits the seventh hypothesis "H7": "There is statistically significant correlation between the negative evaluation of IT infrastructure and the negativity of e-services quality based on perceptions of IT managers and IT specialists." While the last hypothesis "H8": There is statistically significant correlation between the negative evaluation of IT infrastructure and the negativity of system quality based on perceptions of IT managers and IT specialists."

\subsubsection{User satisfaction (STS)}

It's helpful to measure user satisfaction with a given IS in order to understand IS success; especially, when the system is necessary or mandatory for users to perform their duties. This study tries to understand why users not satisfied more than if they are satisfied or not. Users who hold reasonable expectations about an IS tend to be more satisfied with that system[8].Citizens lack strong motivations to use E-Gov services is one of barriers of use E-Gov in Europe [12]. All the study results conducted in Jordan indicated that Jordanians unsatisfied about E-Gov services (as discussed in [6], [9], [10], [17], [24]). For instance,Al-shboul et al. [17], reportedthat 70 percent of E-Govusers found it not useful. AlsoAbu-Shanab et al.[10], claimed that usage of EGov services not exceed 36 percent in north of Jordan.Thus, this study tries to answer why Jordanians unsatisfied with provided services to them. Therefore, this study results could help the service providers to reform E-Gov policy in order to provide more mature services and satisfy the recipient's needs. 
International Journal of Managing Public Sector Information and Communication Technologies (IJMPICT) Vol. 9, No. 2, June 2018

\section{RESEARCH METHODOLOGY}

\subsection{Data Collection}

IT managers and IT professionals of government agencies are the most proper respondents to evaluate E-Gov success at national level. Ministry of information and communication technology (MoICT) provisioned researchers a list of contacts information (emails and phone numbers) of IT managers and IT professionals. The list contains 153 IT managers and specialists whom in charged to follow-up with MoICT the E-Gov program execution in behalf of their departments across of government. Therefore, no need to apply any sampling technique because we can send the questionnaire to all of them. The reasons to target IT managers and IT professionals of government agencies are: they are responsible to frame IT strategy of their departments; They are responsible about E-Gov services provided by their departments; and More aware about challenges of E-Gov related to their departments, thus awareness of E-Gov challenges over all(see[34]). Table 4contains brief information about respondents, where $41 \%$ they are IT managers in addition 7\% head of IT sections of small departments; the rest of sample from interdisciplinary of IT. They invited to answer the questionnaire via Google form sent directly to their formal emails between March and June 2017. We reminded and encouraged the respondents to answer questionnaire through sending the questionnaire link by email more than one time, by phone call and personal visit to their offices.

Table 4 Sample information

\begin{tabular}{|l|c|c|c|c|c|}
\hline Position & Total & Academic degree & Total & Gender & Total \\
\hline IT Managers & 39 & Bachelor & 50 & Male & 72 \\
\hline Head of EGov\& IT Section & 6 & Master & 39 & Female & 21 \\
\hline Network Administrator & 18 & PhD & 4 & & \\
\hline Database Administrator & 4 & Total & $\mathbf{9 3}$ & & $\mathbf{9 3}$ \\
\hline Computer \& System Engineer & 4 & Experience & & & \\
\hline IT teacher (E-Gov trainers) & 6 & Over 15 years & 30 & & \\
\hline Programmer & 11 & $11-15$ years & 25 & & \\
\hline Business analyst, Quality Control & 2 & 5-10 years & 26 & & \\
\hline Technical Support Engineer & 3 & $1-4$ years & 12 & & \\
\hline
\end{tabular}

\subsection{Measurements of Hypotheses}

The study main question is "How do you evaluate the impact of E-Gov barriers on dissatisfaction of E-Gov users (The measurement of E-Gov success)"? IT managers and IT specialists asked to answer the main question through answering the sub-questions, (a) How do you evaluate the quality of E-Gov systems' in light of barriers you experienced? (b) How do you evaluate the quality of E-Gov information in light of barriers you experienced? (c) How do you evaluate the quality of E-Gov services in light of barriers you experienced? The last question was about (d) your perception for impact of the shortage of IT infrastructure readiness on dissatisfaction of EGov users'. The respondents answered the degree of user's dissatisfactionbased on their experience with E-Gov users by two items: (a) Recipients not satisfy with available e-government services and (b) The recipients feeling that e-services unsecured.The survey instrument was developed using items adopted and/or adapted from previous studies mainly from "IS success model"(see Appendix A). The pilot study tested the survey instrument by IT professors, PhD students and IT professionals from public sector. The goal of the pilot study was to validate the instrument and to test its reliability. The pilot study allowed for evaluating measurements of each suggested factor and modifications were made accordingly. Pilot participants not participated in 
International Journal of Managing Public Sector Information and Communication Technologies (IJMPICT)

Vol. 9, No. 2, June 2018

the subsequent study. At beginning of questionnaire, the respondents asked to self-report their experience period in last position, job title and general information about their organization. The respondents answered the questionnaire using a seven Likert scale, with value ranging between 1 (very strongly disagree) to 7 (very strongly agree).

\section{Data Analysis AND Results}

Regarding to the available sample and the exploratory nature of the study, Partial Least Squares (PLS) preferred over covariance based structural equation modeling (CBSEM) because more appropriate for handling small sample, along with robustness but factor loading should be greater than (0.7)[36].The advantages of PLS include ability to model multiple dependents as well as multiple independents; ability to handle multicollinearity among the independents; robustness in the face of data noise and missing data; and creating independent latent variables directly on the basis of cross-products involving the response variable(s), making for stronger predictions[37]. The PLS-SEM selected for its superior statistical power in dealing with complex causal modeling such as communication and behavioral researches[38]. The study met the sample size criteria to use PLS, where should be: (1) ten times the largest number of formative indicators used to measure one construct; or (2) ten times the largest number of structural paths directed at a particular latent construct in the structural model[39]. The Outer Loadings, Composite Reliability, Average Variance Extracted (AVE), and discriminant validity all employed to assess the measurement model. The path coefficient and t-value were used to examine the structural model relations.

\subsection{Measurement Model}

The assessment of measurement model includes composite reliability (CR) to evaluate internal consistency[37], [38].The CR values for full sample and the sub-samples are higher than 0.7, suggesting that scales are reliable. The sufficient degree of convergent validity when the AVE is greater than 0.50. The result inTable 5indicate that AVE for both sub-sample and full sample are greater than 0.5 .

Table 5 AVE and CR Results

\begin{tabular}{|c|c|c|c|c|c|c|}
\hline \multirow{2}{*}{ Sample } & \multicolumn{2}{|c|}{ Full sample } & \multicolumn{2}{c|}{ IT managers } & \multicolumn{2}{c|}{ Other IT specialists } \\
\cline { 2 - 7 } Factor & CR & AVE & CR & AVE & CR & AVE \\
\hline \multirow{2}{*}{ INFOQ } & 0.9 & 0.69 & 0.89 & 0.68 & 0.9 & 0.7 \\
\hline ITINFRA & 0.8 & 0.57 & 0.83 & 0.62 & 0.77 & 0.53 \\
\hline & & & & & & \\
STS & 0.87 & 0.77 & 0.87 & 0.77 & 0.87 & 0.78 \\
\hline SERVQ & 0.93 & 0.77 & 0.92 & 0.74 & 0.94 & 0.81 \\
\hline
\end{tabular}

The discriminant validity of the constructs was assessed using Fornell- Larcker criteria, crossloadings, and Heterotrait-Monotrait Ratio (HTMT).According to the Fornell-Larcker criterion, the square root of the AVE of each construct should be higher than the construct's highest correlation with any other construct in the model[40]. Overall, the square roots of the AVEs in Table 6 for the reflective constructs INFOQ (0.83), ITINFRA (0.76), SERVQ (0.88), SYSQ (0.76) and STS (0.94) are all higher than the correlations of these constructs with other latent variables in the path model, thus indicating all constructs are valid measures of unique concepts. 
International Journal of Managing Public Sector Information and Communication Technologies (IJMPICT)

Vol. 9, No. 2, June 2018

Table 6 Fornell-Larcker Criteria

\begin{tabular}{|c|c|c|c|c|c|}
\hline & INFOQ & ITINFRA & STS & SERVQ & SYSQ \\
\hline INFOQ & $\boldsymbol{0 . 8 3}$ & & & & \\
\hline ITINFRA & 0.32 & $\mathbf{0 . 7 6}$ & & & \\
\hline STS & 0.45 & 0.5 & $\mathbf{0 . 9 4}$ & & \\
\hline SERVQ & 0.48 & 0.51 & 0.65 & $\boldsymbol{0 . 8 8}$ & \\
\hline SYSQ & 0.6 & 0.56 & 0.44 & 0.5 & $\mathbf{0 . 7 6}$ \\
\hline
\end{tabular}

According to cross-loadings, the discriminant validity will establish when an indicator's loading on its assigned construct is higher than all its cross-loadings with other constructs[41]. Table 7shows the outer loading and cross-loadings for every indicator. All the indicators values are higher than its entire corresponding construct (e.g., Infol on INFOQ: 0.75 higher than all crossloadings with other constructs).

Table 7 Cross-loading

\begin{tabular}{|c|c|c|c|c|c|}
\hline $\begin{array}{c}\text { Factor } \\
\text { Indicators }\end{array}$ & INFOQ & ITINFRA & STS & SERVQ & SYSQ \\
\hline Info1 & $\mathbf{0 . 7 5}$ & 0.17 & 0.29 & 0.17 & 0.43 \\
\hline Info2 & $\mathbf{0 . 8 7}$ & 0.28 & 0.46 & 0.4 & 0.48 \\
\hline Info3 & $\mathbf{0 . 8 3}$ & 0.19 & 0.31 & 0.32 & 0.56 \\
\hline Info4 & $\mathbf{0 . 8 6}$ & 0.39 & 0.51 & 0.49 & 0.51 \\
\hline ITinfra1 & 0.25 & $\mathbf{0 . 7 9}$ & 0.31 & 0.28 & 0.55 \\
\hline ITinfra2 & 0.19 & $\mathbf{0 . 7 5}$ & 0.25 & 0.22 & 0.46 \\
\hline ITinfra3 & 0.27 & $\mathbf{0 . 7 4}$ & 0.54 & 0.78 & 0.31 \\
\hline Sts1 & 0.45 & 0.48 & $\mathbf{0 . 8 8}$ & 0.57 & 0.54 \\
\hline Sts2 & 0.4 & 0.42 & $\mathbf{0 . 8 8}$ & 0.61 & 0.34 \\
\hline Serv1 & 0.38 & 0.49 & 0.6 & $\mathbf{0 . 9 5}$ & 0.38 \\
\hline Serv2 & 0.45 & 0.47 & 0.61 & $\mathbf{0 . 9 3}$ & 0.48 \\
\hline Serv3 & 0.43 & 0.45 & 0.62 & $\mathbf{0 . 9 4}$ & 0.38 \\
\hline Sys1 & 0.65 & 0.25 & 0.38 & 0.31 & $\mathbf{0 . 8 1}$ \\
\hline Sys2 & 0.55 & 0.29 & 0.37 & 0.36 & $\mathbf{0 . 7 9}$ \\
\hline Sys3 & 0.43 & 0.53 & 0.44 & 0.55 & $\mathbf{0 . 7 7}$ \\
\hline Sys4 & 0.29 & 0.52 & 0.34 & 0.16 & $\mathbf{0 . 7 4}$ \\
\hline Sys5 & 0.35 & 0.56 & 0.38 & 0.22 & $\mathbf{0 . 7 1}$ \\
\hline & & & & & \\
\hline
\end{tabular}

In light of the limitations of cross-loadings and the Fornell-Larcker criterion, an alternative, more reliable criterion should be applied such as Heterotrait-Monotrait Ratio (HTMT). Especially, the HTMT-based assessment using a confidence interval relies on inferential statistics. However, the latter two measures still constitute standard means for discriminant validity assessment. An HTMT value above 0.90 suggests a lack of discriminant validity. When the constructs in the path model are conceptually more distinct, a lower and thus more conservative threshold value of 0.85 seems warranted[41]. The Table 8shows HTMT values for all pairs of constructs in a matrix format. As can be seen, all HTMT values are clearly lower than conservative threshold value of 0.85 . 
International Journal of Managing Public Sector Information and Communication Technologies (IJMPICT)

Vol. 9, No. 2, June 2018

Table 8 Hetetrotrait-Monotriat Ratio

\begin{tabular}{|c|c|c|c|c|c|}
\hline & INFOQ & ITinfra & SERVQ & STS & SYSQ \\
\hline INFOQ & & & & & \\
\hline ITinfra & 0.41 & & & & \\
\hline SERVQ & 0.48 & 0.72 & & & \\
\hline STS & 0.61 & 0.71 & 0.80 & & \\
\hline SYSQ & 0.71 & 0.79 & 0.48 & 0.66 & \\
\hline
\end{tabular}

The second requirements to detect the discriminant validity for HTMT when HTMT values are significantly different from 1[40]. Conversely, if the value 1 falls outside the interval's range, this suggests that the two constructs are empirically distinct. This requires computing bootstrap confidence intervals obtained by running the bootstrapping option. The columns labeled $2.5 \%$ and $97.5 \%$ show the lower and upper bounds of the $95 \%$ confidence interval. As can be seen, neither of the confidence intervals includes the value 1. The results inTable 9of the HTMT criterion alsoclear evidence of the discriminant validity of the constructs.

Table 9BootstrapConfidence Interval

\begin{tabular}{|l|c|c|c|c|}
\hline & Original Sample & Sample Mean & Lower Bound & $\begin{array}{c}\text { Upper } \\
\text { Bound }\end{array}$ \\
\hline ITinfra -> INFOQ & 0.41 & 0.45 & 0.2 & 0.68 \\
\hline SERVQ -> INFOQ & 0.48 & 0.48 & 0.3 & 0.64 \\
\hline SERVQ -> ITinfra & 0.59 & 0.59 & 0.37 & 0.77 \\
\hline STS -> INFOQ & 0.61 & 0.61 & 0.38 & 0.82 \\
\hline STS -> ITinfra & 0.71 & 0.72 & 0.48 & 0.89 \\
\hline STS -> SERVQ & 0.8 & 0.8 & 0.61 & 0.96 \\
\hline SYSQ -> INFOQ & 0.71 & 0.71 & 0.51 & 0.86 \\
\hline SYSQ -> ITinfra & 0.79 & 0.81 & 0.58 & 0.97 \\
\hline SYSQ - > SERVQ & 0.48 & 0.48 & 0.29 & 0.65 \\
\hline SYSQ -> STS & 0.66 & 0.66 & 0.44 & 0.82 \\
\hline
\end{tabular}

For uniqueness of evaluating E-Gov quality based on negative perspectives of E-Govdomain, we make sure E-Gov quality model passed all the possible validity and reliability criteria, which support credibility of study results.

\subsection{Structural Model}

Examining the correlation in Table 6 for evidence of multicollinearity among exogenous constructs shows that the highest correlation between exogenous constructs is 0.65 . As well as, variance inflation factors (VIF) are lower than the conservative threshold of 5. This suggests that there are no concerns of multicollinearity[40]. The analysis of hypotheses was based on the examination of the standardized paths. The path significance levels were estimated using the bootstrapping method (3000 re-samples). The results of the analysis are summarized in Table 10. The full sample results reveled that all suggested hypotheses are significant at a 5\% level except the impact of system quality (SYSQ) on services quality (SERVQ). Thus, the hypotheses H2, H3, $\mathrm{H} 4, \mathrm{H} 5, \mathrm{H} 6, \mathrm{H} 7$ and $\mathrm{H} 8$ confirmed while $\mathrm{H} 1$ rejected. However, the results based on IT managers' opinions just indicate significant correlations between (a) IT infrastructure readiness (ITinfra) with SYSQ; (b) services quality always important factor to detect users satisfaction (STS); (c) and system quality definitely affect the information quality (INFOQ).Thus, hypotheses $\mathrm{H} 2$, $\mathrm{H} 5$, and $\mathrm{H} 8$ confirmed while $\mathrm{H} 1, \mathrm{H} 3, \mathrm{H} 4, \mathrm{H} 6$ and $\mathrm{H} 7$ rejected. Although, IT specialists agree with IT managers about significant correlation of system quality with information quality, service 
International Journal of Managing Public Sector Information and Communication Technologies (IJMPICT)

Vol. 9, No. 2, June 2018

quality with users' satisfaction and IT infrastructure with system quality. However, according to IT specialists, hypotheses $\mathrm{H} 2, \mathrm{H} 3, \mathrm{H} 5, \mathrm{H} 7$ and $\mathrm{H} 8$ confirmed while $\mathrm{H} 1, \mathrm{H} 4$, and $\mathrm{H} 6$ rejected. Interestingly, IT managers and IT specialists agree together that there is no correlation between system quality and services quality.In contrast, Hypotheses H2: SYSQ -> INFOQ; H5: SERVQ $>$ STS and H8: ITinfra -> SYSQ, confirmed significant correlation at all levels full sample and sub-groups.The only difference between female and male group that male group reported insignificant relation while female group found SYSQ has negative relation with SERVQ. We examined the $\mathrm{R}^{2}$ values of the endogenous latent variables for the full sample, which are available in last row of Table 10. The $\mathrm{R}^{2}$ values of, and STS (0.51) SREVQ (0.48) can be considered moderate, whereas the $\mathrm{R}^{2}$ values of INFOQ (0.36)and SYSQ (0.30) are rather weak. The research model explains $51 \%$ of the reasons ledto dissatisfaction of recipients about E-Gov services. Consequently, the E-Gov unsuccessful from perspectives of IT managers and IT specialists. The total effect result indicated that IT The findings indicate that the research model is significant in explaining the dissatisfaction of E-Gov users based on opinions of government agencies. The total effect results indicated that ITinfra (0.53) has the highest impact on STS, which is higher than total effect of SERVQ (0.48), INFQ (0.36) and SYSQ (0.20) respectively. Furthermore, ITinfra has high total effect on SERVQ (0.65), SYSQ (0.55) and INFOQ (0.33),respectively. Therefore, Infrastructure readiness (ITinfra) is extremely important for SERVQ, and SYSQ. The $\mathrm{F}^{2}$ results revealed that ITinfra has $(45 \%)$ size of effect on SERVQ and (43\%) on STS. As well as, $\mathrm{f}^{2}$ test revealed that SYSQhighly contribute $(56 \%)$ to INFOQ. The SYSQ is a key player to determine the level of INFOQ. The SERVQ is a major driver to determine the degree of users' satisfactions (STS). The result of path coefficient based on IT specialists' opinions similar to full sample. While IT managers give equal importance for the relationship of IT infrastructure readiness (ITinfra) with SYSQ and SERVQ with satisfaction (STS).

Table 10 Relevant construct for structure model

\begin{tabular}{|c|c|c|c|c|c|c|}
\hline & \multicolumn{2}{|c|}{ Full sample } & \multicolumn{2}{|c|}{ IT managers } & \multicolumn{2}{|c|}{ Other IT specialists } \\
\hline & T-value & Path coeff. & T-value & $\begin{array}{l}\text { Path } \\
\text { coeff. }\end{array}$ & T-value & Path coeff. \\
\hline H1: SYSQ -> SERVQ & 0.37 & 0.05 & 0.71 & 0.18 & 0.19 & -0.04 \\
\hline H2: SYSQ -> INFOQ & 7.4 & 0.60 & 2.88 & 0.50 & 8.91 & 0.69 \\
\hline H3: INFOQ -> STS & 2.16 & 0.22 & 0.11 & 0.02 & 2.70 & 0.43 \\
\hline H4: INFOQ -> SERVQ & 2.19 & 0.29 & 1.84 & 0.37 & 0.95 & 0.17 \\
\hline H5: SERVQ -> STS & 4.01 & 0.44 & 3.76 & 0.57 & 3.16 & 0.44 \\
\hline H6: ITinfra -> STS & 2.22 & 0.22 & 1.82 & 0.28 & 0.42 & 0.06 \\
\hline H7: ITinfra -> SERVQ & 3.17 & 0.38 & 1.28 & 0.27 & 2.95 & 0.52 \\
\hline H8: ITinfra -> SYSQ & 6.46 & 0.56 & 4.79 & 0.57 & 4.85 & 0.60 \\
\hline
\end{tabular}




\section{DISCUSSION}

The E-Gov success becomes urgent necessary with rapid technological developments and increasing difficulty of daily life, specifically in developing countries. Governments in these countries are responsible for fulfilling their promises to harvest the advantages of electronic transformation. The first step toward E-Gov successful is to define the current E-Gov problems clearly in order to find the appropriate solutions as this study wish to do. The results show that challenges imbedded in the four factors are the main causative to hinder E-Gov success(see Table 10). The results are varying based in the opinions of sub-groups IT managers and IT specialists(see Table 10). Although System quality did not affect SERVQ directly, barriers of system quality significantly affect information quality negatively that aggravated of users' dissatisfaction about E-Gov services (represented by H1and H3).The study confirmed the barriers related to system quality mentioned by[14], [15], [26]. The barriers of information quality reflexed the evaluation of SERVQ negatively (H4). The studyresultsindicated that lack of security is the strongest barrier of system quality that leads to the negativity of information quality. Here we found that the barriers related to system quality such as lack of security, lack of compatibility, integration difficulty, and system overload and system breakdown. These challenges will result in shortage for information quality such as complicated information flowing, inaccessibility for authorized users, information inaccuracy, and timeline to get and publish E-Govinformation. The full sample results indicated that system quality have indirect effect on users' satisfaction. The negative assessments of information quality and services quality have provoked users dissatisfaction about E-Gov services (as indicated by H4 and H5).However, sub-groups result indicated that IT managers and IT specialists separately, have the same perception toward system quality. System quality significantly affect in negativity of information quality, where it's unlike to affect in services quality. However, based on gender groups females found the low of system quality is responsible directly about the poor services quality. The male group found system quality affected service through information quality, not directly like female group. The lack of IT infrastructure readiness seems to be the main drawback of E-Gov success. Synchronously, IT infrastructure readiness significantly correlated with negativity assessment of system quality and services quality as well the dissatisfaction of E-Govusers, (H6, H7 and H8). Lack of IT infrastructure readiness hindering government agencies to provide new e-services, improving current services and responding for users' needs appropriately. As well as, its aggravated system quality barriers. Thus, IT infrastructure unreadiness significantly play a pivotal role in users' dissatisfaction consequently E-Gov failure. Obviously, IT infrastructure is a key factor to determine the level of SYSQ because it's the platform to operate the E-Gov systems.The results show that IT infrastructure readiness is the most important factor to affect users' satisfaction as well the strongest influential. More precisely, the need to decrease maintenance cost of IT resources (obsolesce of IT resources e.g. servers, networks ...etc.) it was the strongest indictor among indicators of IT infrastructure readiness. This result align withPetter et al.[8], when they found that IT infrastructure the second strongest predictor of IS success based on results the systematic review (1992-2007) for the studies that adopted IS success model. The United Nations assessment of E-Govs affirmed this resultespecially in regard to IT infrastructure readiness where all assessments until 2016 show Jordan below the world average (see Table 2). The negative assessment for e-services strongly provoked users dissatisfaction. This result confirmed the UN assessments the low average of online services quality in Jordan (see Table 2). As well as, consistent withAl-Soud et al.[9], result that 70 percent of who used the E-Gov services found it not useful.

\section{CONCLUSION}

The study defined very important gaps related to E-Gov barriers. Firstly, IT infrastructure gap where government responsible to provide cutting-edge technology and sufficient IT resources.The provision IT resources should not be limited to capital city and big cities, more 
International Journal of Managing Public Sector Information and Communication Technologies (IJMPICT) Vol. 9, No. 2, June 2018

attention needed to rural areas and small cities to underpin IT infrastructure. The readiness of IT infrastructure is very important platform for government online and in-house systems and for the continuity of e-services. Thus, government agencies will be able to provide more secure online services tosatisfy users and citizen expectations.Secondly, gap related to system quality where found the security issue among the strongest barriers to hinder E-Gov performance. Lackcompatibility and integration between systems of E-Gov clear evidence to damage the information quality. Also, unexpected breakdown and the system overload need to be improved. These barriers should be managed and discussed with all partners and key stakeholders to set up clear policy for better alignmentof E-Gov systems to guarantee efficiency interoperability between them.Thirdly, barriers related to information quality could be resolved through remedying system quality issues. The government agencies have to share accurate information with all partners and provide information in the right time via secure channel. In this context IT departments have more efforts to update website's information and systems outputs. The employees in government should have enough authority to access the information that needed for their jobs. Fourthly the results spoke clearly that provided e-services are less than expectation of stakeholders and participants. Therefore, we suggest government to rank services based on priority for citizens, business sector and government sector. Then government starts to release these services completely online for each sector.Government agencies are required to re-engineer procedures to provide the services in order to be available online smoothly, more efforts needed for shared services with more than one department. Reforming E-Gov program needs incorporate all efforts in order to put E-Govprogram on success path. Although, the study sample consist more than third of IT managers in government, but it's results still far away from generalizability. The model construct is limited to technological aspects because the social, cultural and organizational dimensions have been investigated sufficiently by Jordanian researchers as well worldwide. The E-Gov barriers discussed from the viewpoints of service providers whose responsible about releasing the e-services from government agencies. However, the model still can be applied in other countries and its flexible to modification. The study tested the IS success model in negative context that may pave researchers' way to conduct more studies in such context.

\section{ACKNOWLEDGEMENT}

We thank for partial finance support for this work by Ministry of Science and Technology, Taiwan (grant number: MOST 106-2410-H-327 -025).Thanks to Dr. Daniela López De Luise, we highly appreciate you taking the time out to share your experience with us. Thank you for valuable comments and suggestions.

\section{Appendix A. Constructs and Items}

\begin{tabular}{|c|l|c|c|}
\hline Code & \multicolumn{1}{|c|}{ Items statements } & $\begin{array}{c}\text { Outer } \\
\text { loading }\end{array}$ & T-value \\
\hline System quality (SYSQ) adapted from [8], [12], [15], [16] & 0.82 & 14.86 \\
\hline SYS1 & Difficulty to integrate different e-government systems & 0.8 & 14.19 \\
\hline SYS2 & Lack of compatibility between e-government systems. & 0.79 & 17.85 \\
\hline SYS3 & Information systems overload over normal rate (slow processing). & 0.72 & 7.13 \\
\hline SYS4 & Need to reduce systems breakdown. & 0.694 & 7.8 \\
\hline SYS5 & Need to make systems more secure. & & \\
\hline Information quality (INFOQ) adapted from [8], [42] & 0.751 & 7.48 \\
\hline INFO1 & Information flowing among e-government systems cumbersome. & 30.35 \\
\hline INFO2 & $\begin{array}{l}\text { Sometime information retrieved from e-government systems not } \\
\text { accurate. }\end{array}$ & 0.874 & 13.07 \\
\hline INFO3 & Timeline problem to get/publish required information. & 0.831 & 18.91 \\
\hline INFO4 & $\begin{array}{l}\text { Accessibility problem to e-government information for authorized } \\
\text { users. }\end{array}$ & 0.86 & 24.91 \\
\hline
\end{tabular}


International Journal of Managing Public Sector Information and Communication Technologies (IJMPICT)

Vol. 9, No. 2, June 2018

\begin{tabular}{|c|l|c|c|}
\hline \multicolumn{2}{|l|}{ E-services quality (SERVQ) adapted [8], [9] } & 0.909 & 40.69 \\
\hline SERV1 & Unable to improve current e-services. & 0.911 & 36.8 \\
\hline SERV2 & Unable to provide new e-services. & 0.913 & 41.54 \\
\hline SERV3 & Unable to response for our recipients' needs & 0.764 & 8.05 \\
\hline \begin{tabular}{c} 
IT infrastructure readiness (ITinfra) adapted from [7], [14], [15], [23] \\
\hline $\begin{array}{c}\text { ITinfra } \\
1\end{array}$
\end{tabular} & Need to reduce cost of electricity consumed by IT resources. & 5.87 \\
\hline $\begin{array}{c}\text { ITinfra } \\
2\end{array}$ & $\begin{array}{l}\text { Need to decrease maintenance cost of IT resources (obsolesce of IT } \\
\text { resources e.g. servers, networks ...etc.). }\end{array}$ & 0.723 & 10.9 \\
\hline $\begin{array}{c}\text { ITinfra } \\
3\end{array}$ & Lack of IT infrastructure adequacy. & 0.78 & \\
\hline Users satisfaction (STS) adapted from [8] & 0.88 & 28.87 \\
\hline STS1 & Recipients not satisfy with available e-government services. & 0.88 & 30.62 \\
\hline STS2 & Recipients perceive e-government services unsecured. & & \\
\hline
\end{tabular}

\section{References}

[1] United Nations, "E-Government for the Future We Want," New York, USA, 2014.

[2] A. Rorissa, D. Demissie, and T. Pardo, "Benchmarking e-Government: A comparison of frameworks for computing e-Government index and ranking," Gov. Inf. Q., vol. 28, no. 3, pp. 354$362,2011$.

[3] J. Lee, "10year retrospect on stage models of e-Government: A qualitative meta-synthesis," Gov. Inf. Q., vol. 27, no. 3, pp. 220-230, 2010.

[4] T. Obi, "2015 WASEDA - IAC INTERNATIONAL E-GOVERNMENT RANKING SURVEY," Tokyo, 2015.

[5] United Nations, "E-Government in Support of Sustainable Development," New York, USA, 2016.

[6] Y. Elsheikh, A. Cullen, and D. Hobbs, "e-Government in Jordan: challenges and opportunities," Transform. Gov. People, Process Policy, vol. 2, pp. 83-103, 2008.

[7] N. P. Rana, Y. K. Dwivedi, and M. D. Williams, "Analysing challenges, barriers and CSF of egov adoption," Transform. Gov. People, Process Policy, vol. 7, no. 2, pp. 177-198, 2013.

[8] S. Petter, W. DeLone, and E. R. McLean, "Information systems success: The quest for the independent variables," J. Manag. Inf. Syst., vol. 29, no. 4, pp. 7-62, 2013.

[9] A. R. Al-Soud, H. Al-Yaseen, and S. H. Al-Jaghoub, "Jordan's e-Government at the crossroads," Transform. Gov. People, Process Policy, vol. 8, pp. 597-619, 2014.

[10] E. Abu-Shanab, S. A. Al-Rub, and K. M. Nor, "Obstacles Facing the Adoption of E-government Services in Jordan," J. E-Governance, vol. 33, pp. 34-47, 2010.

[11] United Nations, "E-Government Development Index (EGDI)," 2017. [Online]. Available: https://publicadministration.un.org/egovkb/en-us/Data/Country-Information/id/86-Jordan. [Accessed: 07-May-2017].

[12] R. Eynon and W. H. Dutton, "Barriers to networked governments: Evidence from Europe," Prometh. Crit. Stud. Innov., vol. 25, no. 3, pp. 225-242, 2007.

[13] Z. Ebrahim and Z. Irani, "E-government adoption: architecture and barriers," Bus. Process Manag. J., vol. 11, no. 5, pp. 589-611, 2005.

[14] A. Savoldelli, C. Codagnone, and G. Misuraca, "Understanding the e-government paradox: Learning from literature and practice on barriers to adoption," Gov. Inf. Q., vol. 31, pp. S63-S71, 2014.

[15] W. Lam, "Barriers to e-government integration,” J. Enterp. Inf. Manag., vol. 18, no. 5, pp. 511530, 2005.

[16] L. Waller and A. Genius, "Barriers to transforming government in Jamaica," Transform. Gov. People, Process Policy, vol. 9, no. 4, pp. 480-497, 2015.

[17] M. Al-shboul, O. Rababah, M. Al-shboul, and R. Ghnemat, "Challenges and Factors Affecting the Implementation of E-Government in Jordan," J. Softw. Enginerring Apllication, vol. 7, no. December, pp. 1111-1127, 2014.

[18] R. Schwester, "Examining the Barriers to e-Government Adoption," Electron. J. e-Government, vol. 7, no. 1, pp. 113-122, 2009.

[19] E. Lau, "Challenges for E-Government Development," in 5th Global Forum on Reinventing Government, 2003, no. November, pp. 1-18. 
International Journal of Managing Public Sector Information and Communication Technologies (IJMPICT)

Vol. 9, No. 2, June 2018

[20] F. Salem, "Exploring e-Government Barriers in the Arab States," Policy Br., vol. 2, 2006.

[21] J. Rose, J. S. Persson, L. T. Heeager, and Z. Irani, "Managing e-Government: Value positions and relationships," Inf. Syst. J., vol. 25, no. 5, pp. 531-571, 2015.

[22] O. (Richard) Ashaye and Z. Irani, "E-government Implementation Benefits, Risks, and Barriers in Developing Countries: Evidence From Nigeria," in 2nd International Conference on Information Technology, E-Government and Applications ( ICITEA ), 2013, pp. 92-105.

[23] Q. N. Nkohkwo and M. S. Islam, "Challenges to the Successful Implementation of e-Government Initiatives in Sub-Saharan Africa : A Literature Review," Electron. J. e-Government, vol. 11, no. 2, pp. 253-267, 2013.

[24] M. Alomari, K. Sandhu, and P. Woods, "Exploring citizen perceptions of barriers to e-government adoption in a developing country," Transform. Gov. People, Process Policy, vol. 8, no. 1, pp. 131150, 2014.

[25] Y. S. Wang and Y. W. Liao, "Assessing eGovernment systems success: A validation of the DeLone and McLean model of information systems success," Gov. Inf. Q., vol. 25, no. 4, pp. 717-733, 2008.

[26] L. F. Luna-Reyes, J. R. Gil-Garcia, and G. Romero, "Towards a multidimensional model for evaluating electronic government: Proposing a more comprehensive and integrative perspective," Gov. Inf. Q., vol. 29, no. 3, pp. 324-334, 2012.

[27] D. Stefanovic, U. Marjanovic, M. Delić, D. Culibrk, and B. Lalic, "Assessing the success of egovernment systems: An employee perspective,” Inf. Manag., vol. 53, no. 6, pp. 717-726, 2016.

[28] S. Petter, W. DeLone, and E. McLean, "Measuring information systems success: models, dimensions, measures, and interrelationships," Eur. J. Inf. Syst., vol. 17, no. 3, pp. 236-263, 2008.

[29] S. Petter and E. R. McLean, "A meta-analytic assessment of the DeLone and McLean IS success model: An examination of IS success at the individual level," Inf. Manag., vol. 46, no. 3, pp. 159166, 2009.

[30] C. W. Chen, "Impact of quality antecedents on taxpayer satisfaction with online tax-filing systemsAn empirical study," Inf. Manag., vol. 47, no. 5-6, pp. 308-315, 2010.

[31] S. Angelopoulos, F. Kitsios, P. Kofakis, and T. Papadopoulos, "Emerging barriers in e-government implementation," in In Electronic Government, vol. 6228 LNCS, Springer Berlin Heidelberg, 2010, pp. 216-225.

[32] M. A. Shareef, V. Kumar, U. Kumar, and Y. K. Dwivedi, "E-Government Adoption Model (GAM): Differing service maturity levels," Gov. Inf. Q., vol. 28, no. 1, pp. 17-35, 2011.

[33] D. Gilbert, P. Balestrini, and D. Littleboy, "Barriers and benefits in the adoption of e-government," Int. J. Public Sect. Manag., vol. 17, no. 4, pp. 286-301, 2004.

[34] T. Obi, "International Digital Government Rankings 2017," Tokyo, 2017.

[35] J. Liang, "Government cloud: Enhancing efficiency of E-government and providing better public services," in International Joint Conference on Service Sciences Government, 2012, pp. 261-265.

[36] G. D. Garson, Partial Least Squares: Regression \& Structural Equation Models, 2016th ed. Asheboro: NC: Statistical Associates Publishers., 2016.

[37] P. B. Lowry and J. Gaskin, "Partial least squares (PLS) structural equation modeling (SEM) for building and testing behavioral causal theory: When to choose it and how to use it," IEEE Trans. Prof. Commun., vol. 57, no. 2, pp. 123-146, 2014.

[38] J. F. Hair Jr, M. Sarstedt, L. Hopkins, and V. G. Kuppelwieser, "Partial least squares structural equation modeling (PLS-SEM)," Eur. Bus. Rev., vol. 26, no. 2, pp. 106-121, 2014.

[39] D. Gefen, E. E. Rigdon, and D. Straub, "An Update and Extension to SEM Guidelines for Administrative and Social Science Research.," MIS Q., vol. 35, no. 2, p. iii-A7, 2011.

[40] J. F. Hair jr, G. T. M. Hult, C. M. Ringle, and M. Sarstedt, A Primer on Partial Least Squares Structural Equation Modeling PLS-SEM), First. Los Angeles, CA: Sage Publications, Inc., 2014.

[41] J. Henseler, C. M. Ringle, and M. Sarstedt, "A new criterion for assessing discriminant validity in variance-based structural equation modeling," J. Acad. Mark. Sci., vol. 43, no. 1, pp. 115-135, 2014.

[42] N. Gorla and T. M. Somers, "The impact of IT outsourcing on information systems success," Inf. Manag., vol. 51, no. 3, pp. 320-335, 2014. 
International Journal of Managing Public Sector Information and Communication Technologies (IJMPICT)

Vol. 9, No. 2, June 2018

Ammar Salamh Mujali Al-rawahna,PhD candidate at College of Business, Southern Taiwan University of Science and Technology, Taiwan, ROC. Email: da21g204@stust.edu.tw. Major areas: E-Business, EGov, Information Management, Human Resources Management, Innovation Management, and Knowledge Management.

Shih-Chih Chen, associate professor at Department of Information Management, National Kaohsiung First University of Science and Technology, Taiwan, ROC. Email: scchen@nkfust.edu.tw.Major areas: electronic commerce, marketing and managerial issues of emerging technologies.

Chung-Wen Hung, professor at Department of Accounting Information, Southern Taiwan University of Science and Technology, Taiwan, ROC. Email: cwhung@stust.edu.tw.Major areas: enterprise resource system and managerial issues of emerging technologies. 